\title{
A Framework To Estimate Loss And Damage (L\&D) To Floods In a Changing Climate, Using Capital- Based Approach
}

Devdyuti Bose ( $\sim$ basudevdyuti92@gmail.com )

Indian Institute of Technology Bombay https://orcid.org/0000-0001-6969-9946

Trupti Mishra

Indian Institute of Technology Bombay https://orcid.org/0000-0002-9473-9919

\section{Research Article}

Keywords: mitigation, Assessment, vulnerability, Catastrophe Simulation

Posted Date: September 21st, 2021

DOI: https://doi.org/10.21203/rs.3.rs-887606/v1

License: (c) (1) This work is licensed under a Creative Commons Attribution 4.0 International License.

Read Full License 


\section{A Framework to Estimate Loss and Damage (L\&D) to Floods in a Changing Climate, using} Capital-based Approach

\section{Introduction}

Floods are one of the frequent hydrological disasters, which have been becoming a severe menace to the mankind and environment (Wallemacq, 2018). According to (IPCC, 2012a) and EM-Dat, the International Disaster Database by Centre for Research on the Epidemiology of Disasters (CRED), flood is defined as the flow of water from a stream channel, or any other water bodies, in excess, of the normal, resulting in submerging of areas, which are dry otherwise. They are mainly caused by climate change, antecedent soil moisture, deforestation, and urbanization (Chang \& Franczyk, 2008). Floods can be of various types- river (fluvial) floods, flash floods and surface water (pluvial) floods, coastal floods, urban floods, sewer floods, and glacial lake outburst floods (GLOF). With $43 \%$ of the disasters, globally, from 1998 to 2017, being floods, they have affected two billion people, and around $23 \%$ of the economic losses, world-wide, due to disasters, have been attributed to floods (Wallemacq, 2018).

Floods are associated with mortality and morbidity effects like deaths due to drowning, physical trauma, electrocution, etc, and incidence of water and vector-borne diseases like diarrhoea, cholera, typhoid, dengue, malaria, etc. (Jonkman \& Kelman, 2005; Doocy et al., 2013;World Health Organization, NA); mental health effects; disruption in provision of health care facilities, due to damage inflicted on physical infrastructure; and injuries during evacuation process (IPCC, 2007; World Health Organization, NA). Besides, they impact personal security through income losses; and inflict damage to their physical capital stock (H. Dewan, 2015; Tripathi, 2015; Paavola, 2017). Such flooding risks will exacerbate with the rising frequency and intensity of pluvial and river floods, in a changing climate (IPCC, 2012b; IPCC, 2021).

Climate model simulations provide empirical evidences that climate change influences the frequency and intensity of floods, and is also projected to increase with increase in greenhouse warming, in future (Balica et al., 2012; Andersen \& Shepherd, 2013; Cai et al., 2014). Besides, advective effects, indicated by changes in sea level pressure, due to changes in global air circulation also contribute to increased rainfall in northwestern and northeastern North America, northern Europe, northern Asia, east coast of Asia, southeastern Australia, and south-central South America (Meehl et al., 2005); and flooding risk increases especially in the mid-to-high latitudes (Trenberth, 2011). The relationship between an increase in sea surface temperature over tropical Indian Ocean and an increase in extreme rainfall events in a global warming scenario suggests an increase in flood risks in central India (Goswami et al., 2006; Rajeevan et al., 2008). A relatively greater increase in flood frequency is projected in the Indian subcontinent basins, under the low emission scenario of Representative Concentration Pathway (RCP) 2.6, as compared to RCP 8.5 (Al et al., 2019). Such increase in flood risks although, can be dealt with flood protection measures (Mishra et al., 2012), but, a shift has been suggested from flood protection to flood risk management approach (Garrote et al., 2019). However, such an approach will yet leave some residual flood losses, known as loss and damage to floods.

This paper is organized as follows: Section 2 introduces the concept of loss and damage, its evolution, and its relevance in the context of floods. The existing methodologies for quantification of loss and damage, across literature, are discussed briefly in Section 3. Section 4 provides a proposed framework on estimation of residual "loss and damage (L\&D)" to floods on the livelihood assets through the lens of the vulnerability context and the capital assets.

\section{Loss and Damage- concept, history, and relevance in floods}

Climate extremes and disasters can neither be used interchangeably, nor there exist any one-to-one relationship between them (IPCC, 2012b). In other words, extreme events like floods pose serious threats to livelihoods, and alter the normal functioning of the prevailing physical, geographical and social conditions of the communities, if their occurrence is accompanied by exposure of communities to floods, and a high degree of vulnerability. It has been suggested that that even though binding mitigation actions can reduce greenhouse gases, yet, there are some residual impacts to which the world is already committed, viz. the sea level rise, frequent and intense cyclones, storm surges, etc., resulting in flooding; hence it is imperative to include adaptation along with mitigation in climate policy actions (IPCC, 2001; Stern, 2007). A host of adaptation measures aimed at reducing vulnerability play an important role in transforming climate extremes to disasters. However, there is a wide array of factors that impede implementation of 
adaptation options, viz. lack of knowledge about climate change, non climatic physical, biological, economic, financial, human resource, social and cultural, and institutional constraints (IPCC, 2014). This leads to soft and hard adaptation limits, resulting in some impacts of climate change that cannot be addressed by adaptation or mitigation. Such impacts are known as residual L\&D. Hence, at the UNFCCC level, there are three pillars of climate actionmitigation, adaptation and loss and damage (Wallimann-Helmer et al., 2019) (Fig. 1)

The concept of L\&D has emerged as an evolving issue in climate policy discourse, and literature has put forward multiple definitions of it, from time to time. Some studies distinguish between losses - impacts that are permanent and irrecoverable, and damages - reversible and repairable impacts (McNamara \& Jackson, 2019; Doelle \& Seck, 2020; Geest \& Warner, 2020). (Okuyama, 2008) also defines damages as the physical destruction to human and physical capital stock, whereas, losses refer to the indirect or secondary effects of a disaster, that lead to changes in production and consumption flows of goods and services. Losses can be economic or non-economic (Fankhauser et al., 2014; McNamara \& Jackson, 2019); and damages can also be direct or indirect, each of which can be tangible (economic) and intangible (social and environmental) (Gajanayake et al., 2020).However, in the emerging literature on L\&D, its definition by (Bouwer, 2011) is limited to damage from sudden or discrete events, and does not include slow onset processes. On the other hand, some studies have attributed L\&D to insufficient adaptation solely, (Action Aid, 2010; Huq et al., 2013; Warner \& Geest, 2013). (UNFCCC, 2012a) also defines L\&D as actual and/or potential manifestation of climate change impacts in developing countries that adversely affect human and natural systems. However, (Geest \& Warner, 2020) defines it as the impacts of climate change that have not been, or cannot be, avoided through mitigation and adaptation efforts.

L\&D can be classified into four categories (Mechler et al., 2019):

a. Avoided L\&D: Avoidable L\&D that $\boldsymbol{c a n}$ or will be avoided by mitigation and/or adaptation;

b. Unavoided L\&D: Avoidable L\&D that will not be avoided by mitigation and/or adaptation; and

c. Unavoidable L\&D: L\&D that cannot be avoided by mitigation and/or adaptation.

The concept of L\&D is further explained with the help of Fig. 2. With no adaptation and no mitigation, costs of climate change will increase at an increasing rate. When policy response is only adaptation or only mitigation, the costs increase at a decreasing rate, but only adaptation leads to relatively higher costs than only mitigation (IPCC, 2007). Although a policy mix of adaptation and mitigation reduce costs of climate change, there are still some residual impacts, known as L\&D.

A household's potential for L\&D depends on his/her mitigation efforts, livelihood context, in forms of capital (social, economic, natural, human, and political), his/her vulnerability profile, and a household's coping and adaptive capacity (Warner \& Geest, 2013). It occurs due to potential four reasons (Warner \& Geest, 2013):

1. Insufficient adaptation or coping measures to avoid loss and damage: Although households adopt adaptation measures to slow onset events or coping measures to extreme events, they fall short of avoiding the impacts of climate change and make them more vulnerable to the adverse effects (Haile et al., 2013; Rabbani et al., 2013; Yaffa, 2013). This results in residual L\&D to the households.

2. Irrecoverable costs (monetary and non-monetary) of adaptation or coping measures: Adaptation or coping measures adopted by households have costs involved, which can be monetary, viz. decline in crop yields due to migration or material losses due to occupational diversification; or can be non-monetary, viz. high opportunity costs involved in migration or loss of occupational and cultural identity due to changing occupation (Brida et al., 2013; Traore \& Owiyo, 2013).

3. Erosive coping measures: Households who are exposed to areas prone to climate risks often employ coping measures which are "erosive" in nature, if the adopted proactive adaptation measures to avoid the adverse effects are not successful. They are erosive, in the sense, that they may prove advantageous in the short term by avoiding the adverse effects, but they eventually pose detrimental effects to their future livelihoods and can impair resilience to climatic stressors in the long run (Haile et al., 2013; Opondo, 2013; Yaffa, 2013)

4. Measures not adopted: There are also many households, who in-spite of being vulnerable to the adverse effects of sudden or slow onset events, do not employ adaptation or coping measures, due tomainly: lack of knowledge required for adaptation or are devoid of skills; too expensive measures for the households to adopt, as they are constrained by financial resources and means (Monnereau \& Abraham, 2013); or do not feel it to be their task to adopt measures to avoid effects; or do not prioritize adaptation or coping. 
Being an uncertain event, it is assumed that the flood loss is also a random variable with a normal distribution, as shown in Fig. 3. The mean and variance of this distribution of flood losses are the expected value, and the cost of risk taken by the residents in floodplains (Thampapillai \& Musgrave, 1985). To minimize the likelihood of occurrence of floods, and their consequences, individuals are endowed with a wide portfolio of adaptation and mitigation measures. Some of these measures are structural (or hard) and non-structural (or soft) measures, where the former includes reservoirs, levees, flood walls, channel improvements, sea dikes, storm-surge barriers, and floodways; and the latter includes land-use planning of flood plains, warning and evacuation, wet proofing, dry flooding, and flood insurance policies (Thampapillai \& Musgrave, 1985; Haque et al., 2010; Garrote et al., 2019; Dua et al., 2020). Although these measures can reduce the expected value of flood losses from $\mu_{0}$ to $\mu_{1}\left(\mu_{1}<\mu_{0}\right)$, and variance from $\sigma_{0}^{2}$ to $\sigma_{1}^{2}\left(\sigma_{1}^{2}<\sigma_{0}^{2}\right)$, there are still some residual flood losses, which is termed as L\&D, the estimation of which is pertinent, to identify the potential room for recovery interventions.

Fig. 4 shows the evolution of L\&D, through various decisions taken in Conference of Parties (COPs), from time to time. The discussion on L\&D dates back to as early as 1991, when a need felt by the communities to address the losses stemming from climate change resulted in the establishment of United Nations Framework Convention on Climate Change (UNFCCC) in the international climate negotiations. It was during this time that the Association of Small Island States (AOSIS) proposal for insurance scheme came up as a compensation scheme for the victims of sea level rise; and this scheme was to be funded by the developed countries, based on their ability to pay and their historical responsibility to emissions. The term "loss and damage" was used in UNFCCC decision, for the first time, in the Bali Action Plan, adopted at COP 13 in 2007. This plan launched the consideration of "disaster risk reduction strategies and means to address loss and damage" due to climate change impacts (UNFCCC, 2008b). AOSIS also proposed a "Multi-Window Mechanism to address Loss and Damage from Climate Change Impacts" at COP 14 in 2008. This mechanism entails three modules: (a) insurance component to address risks associated with climate change induced or weather extreme events; (b) rehabilitation or compensatory component to address L\&D associated with the impacts due to slow onset extreme events; and (c) risk management component (UNFCCC, 2008a). At COP 16, 2010, a work programme to address L\&D was adopted under the Cancun Adaptation Framework. This programme was structured under three thematic areas- assessing risks of L\&D; identification of a range of approaches to address $L \& D$; and explaining the role of Convention for implantation of these approaches (UNFCCC, 2010; UNFCCC, 2011). However, approaches ranging from risk reduction, risk sharing and risk transfer were recognized in "Doha Gateway" at COP 18, 2012, to address L\&D associated with the effects of climate change in vulnerable countries to augment their adaptive capacity (UNFCCC, 2012b). Following the Doha Gateway, a mechanism for L\&D was established at COP 19 in Warsaw, known as Warsaw International Mechanism (WIM) under the Cancun Adaptation Framework (UNFCCC, 2014). It recognized that L\&D extends beyond what can be reduced by adaptation. The key functions of WIM are to strengthen knowledge and understanding of the approaches to address L\&D; to foster dialogue among stakeholders; and finally, to enhance support and action in finance, technology and capacity building, to minimize L\&D. The continuation of WIM was further ensured in the Paris agreement at COP 21, 2015, with a decision to establish a clearing house for risk transfer (UNFCCC, 2016). The structure and effectiveness of WIM was first reviewed at COP 22, 2016, where it had been also decided to conduct reviews periodically, within five years and finance to address L\&D was discussed very briefly, with no concrete outcomes (UNFCCC, 2017). However, at COP 23 in 2017, the Fiji Clearing House for Risk Transfer has been established (UNFCCC, 2018); and the Green Climate Fund Board has been requested to establish an Emergency Response Window for funding projects related to build infrastructure resilient to climate extremes to address L\&D (UNFCCC, 2019).

\section{Methodologies and Frameworks to estimate Loss and Damage to disasters}

Section 3 discusses the various methodologies to estimate L\&D to disasters: Damage and Loss Assessment, Post Disaster Needs Assessment, Catastrophic Simulation, and Hazus-MH tool.

\subsection{Damage and Loss Assessment (DaLA)}

The Damage and Loss Assessment (DaLA), developed by United Nations- Economic Commission for Latin America and the Caribbean (UN-ECLAC), is a bottom-up approach, which makes assessment of the disaster effects by sector to sector, followed by sectoral aggregation to analyse the total disaster effects on the macro-economic aggregates (economic growth, fiscal position, and the balance of payments). The main objective of this assessment is to quantitatively define the financial resources, and define the areas or sectors required for post disaster recovery and reconstruction. The steps involved in this framework (ADB, 2009): (1) develop baseline of physical assets and performance on production and sales (sector-wise) in the area affected, before the disaster; (2) determine total or 
partial destruction to physical assets, and obtain the repair, replacement and construction costs for the damaged ones; (3) examine impact of disaster in each sector (infrastructure, productive, cross-cutting, and social) and subsector (water and sanitation, electricity, transport and communication, housing, education, health, agriculture, manufacturing, environment, etc.), based on various indicators, for pre and post disaster comparison; (4)aggregation of losses and damages across sectors and sub-sectors; and (5) assessing the impact of loss and damage on macroeconomic parameters, like GDP, Balance of Trade, Balance Of Payments, and fiscal budget, for pre-disaster and post-disaster. Various studies have conducted DaLA frameworks to the natural disasters, such as in Sierra Leone by landslide 2017 (World Bank Group, 2017), in Indonesia by December 26, 2004 Tsunami (World Bank Group, 2005), in Turks and Caicos Islands by tropical storm Hanna and Hurricane Ike (CDCC, 2008), etc.

\subsection{Post Disaster and Needs Assessment (PDNA)}

Post Disaster and Needs Assessment (PDNA) is a common integrated, multi sectoral approach to estimate the physical damages, economic losses, and costs of meeting recovery needs after a natural disaster (Jeggle \& Boggero, 2018). It was conducted by UNDP and World Bank's Global Facility for Disaster Reduction and Recovery (GFDRR) in 2017. It encompasses data collection, analysis, and identifies recovery needs, which helps in resource mobilization and development of a comprehensive recovery strategy across multiple sectors of production, infrastructure, human development, cross cutting sectors. The World Bank PDNA is built on the information about the damage and loss obtained by DaLA methodology, coupled with Human Recovery Needs Assessment (Robinson \& Phillips, 2014). The steps involved in PDNA are (GFDRR, 2017a; GFDRR, 2017b): (1) collection of baseline information data for sector specific indicators; (2) assessment of the disaster effects (in monetary terms) on physical infrastructure and assets, governance, production, delivery and access to goods and services, and on risks and vulnerabilities, based on the pre-disaster replacement, repair and reconstruction costs; (3) assessment of consequences of disaster effects, with short, medium and long term implications, for macro-economic impacts, personal or household impacts, and human development impacts; (4) estimation of recovery needs to counter the disaster effects and impacts, for each sector; (5) sector recovery strategy; (6) share the effects and impacts and the identified recovery strategies with the stakeholders, within the sector. The enablers for a successful PDNA are: robust pre and post disaster data sets; partnerships between national and international actors; cooperation among institutions at national level; and coordination between national and sub-national levels (GFDRR, 2017b). 55 PDNAs have been conducted, as of mid-2017 (Jeggle \& Boggero, 2018). It is estimated that total damage and loss of 2015 Nepal Earthquake, Haiti earthquake, and Fani cyclone at Odisha amount to 1.54 billion USD, 7.804 billion USD, and 3454 million USD, respectively; and total recovery needs amount to 76.99 billion USD, 11.5 billion USD, and 4188 million USD, respectively; (World Bank Group, 2010; World Bank Group, 2015; ADB, World Bank, United Nations India, 2019).

\subsection{Catastrophic Simulation (CatSim)}

The government or public authority may face a dearth of funds for financing post disaster relief and recovery, known as financial vulnerability, which mainly, has two components (Mechler et al., 2006): (a) asset risks from natural hazards (measured by the hazard frequency and intensity, exposure and sensitivity); (b) financial resilience or preparedness, i.e. the financial ability of the authority to cope with the disaster losses, with its available resources. The CatSim tool, by the International Institute for Applied Systems Analysis (IIASA), using Monte-Carlo simulation of disaster risks in a particular region, is a non-optimization based assessment tool for budget allocation, and allows the policy makers to test for different alternative scenarios (Hochrainer-Stigler et al., 2015). The stages involved in the CatSim methodology, are as follows: (1) risk of direct asset losses, derived from hazard, exposure and physical vulnerability; (2) financial preparedness of the public sector; (3) financial vulnerability, measured in terms of potential financing gap; (4) illustrating the macroeconomic consequences of the financing gap; and (5) development of strategies to reduce financial vulnerability and build resilience. The first three steps are a part of static risk assessment, and the remaining involve dynamic risk assessment, i.e. assessment of costs and benefits of future disaster risk reduction options and economic impacts, over a given time horizon (Mechler, et al., 2006; Hochrainer-Stigler et al., 2015). CatSim tool, which was implemented in one of the most cyclone active regions, Madagascar, provided estimates of the annual expected losses and the financing gap; and evaluated the risk reduction strategies. It finds that investing in such risk management options can lead to a trade off between economic growth and financial stability (Hochrainer-Stigler et al., 2015). Similarly, a study by (Cardenas et al., 2007), using CatSim tool to assess financial vulnerability of Mexico to earthquake risks, estimates that if an earthquake is expected to occur in Mexico, once in every 20 years, 50 years, 100 years, and 500 years will require relief spending by the government around $\$ 40$ million, $\$ 200$ million, $\$ 2.0$ billion, and $\$ 2.9$ billion, respectively. 


\subsection{Hazus - MH}

The National Institute of Building Sciences (NIBS) has developed a software tool, Hazus-MH to obtain loss estimates at a regional level for hazards like earthquakes, floods and hurricanes. Hazus-MH flood modelling encompasses two parts (Scawthorn et al., 2006a; Scawthorn et al., 2006b): (a) Flood hazard analysis finds the flood depth and velocity in a given area, for riverine or coastal flooding conditions; (b) Flood loss estimation provides direct damage estimates to buildings, essential facilities, crops, vehicles, etc.; induced damage like social losses and the shelter needs of the displaced people; direct losses, viz. the cost of repair or replacement, income loss, crop damage, casualties, etc.; and the indirect losses, like supply shortages, decline in sales, etc. Various studies have conducted flood loss assessments, using Hazus-MH flood models (Nastev \& Todorov, 2013; Yildirim \& Demir, 2019), which also serves the communities for flood mitigation at the local level.

\subsection{Other Methodologies}

Other methodologies used in L\&D estimation are the macro-economic models like Input-Output (I-O) model, Computable General Equilibrium (CGE) model, Social Accounting Matrix (SAM), and econometric models. I-O model is a popular and simple model used to assess the economic impact of disasters and reflects the economic interdependencies, within an economy (Galbusera \& Giannopoulos, 2018); and is integrated with engineering models to yield damage estimates of a disaster. The linearity, rigid structure, and lack of responses to price changes limit the applicability of an I-O model (Okuyama, 2008), an alternative of which used is CGE model. This model incorporates responses of producers and consumers to price changes, aftermath of a disaster (Rose \& Liao, 2005). It can be related to real world economies, by changing production forms, and key model parameters (Kajitani \& Tatano, 2017). Various studies have conducted CGE tools to obtain L\&D estimates to floods (Carrera et al., 2015; Nakajima et al., 2015). SAM models, used to derive damage estimates to disasters are also used in flood impact studies (Sassi \& Sbia, 2010). Unlike CGE, SAM is linear in structure, provides overestimated impacts, and does not respond to price change (Okuyama, 2008). On the other hand, econometric models which are statistically rigorous and provide stochastic estimates are also used in assessing impacts of floods (Zhang, 2016; Hu et al., 2019). (Motschmann et al., 2020) also assessed the L\&D in mountains due to glacier retreat, due to climate change, by considering three dimensions- social impacts of ice loss by perception based survey; glacial hazards by its likelihood, flood extent and magnitude; and variability of water availability by a water balance model.

\subsection{Limitations in existing methodologies}

DaLA and PDNA can capture the full range of disaster impacts till post-disaster, recognizing that impacts aftermath of the disaster have developmental and economic implications (Doktycz \& Abkowitz, 2019). However, some of the major limitations of such frameworks are: (i) inadequate data on various indicators, for baseline situation; (ii) difficulty in replication of social sector assessments, due to their contextual nature; (iii) more attention to infrastructure losses due to disaster; and (iii) assessments only limited to sudden onset events, rather than slow-onset ones. CatSim framework is only limited to financial vulnerability, and it lacks L\&D assessment through lenses of other types of vulnerabilities, viz. physical, social, and environmental, that a region is challenged with, after a disaster. Although Hazus-MH provides us a comprehensive view of L\&D, with its physical and social parameters, it is limited to sudden onset extreme events, and questions the validity of the impact estimation results (Doktycz \& Abkowitz, 2019). Other methodologies, discussed in Section 3.5, assess the impacts of disaster on a macroeconomic scale. Hence, all these methodologies could not address the livelihood context, i.e. the livelihood assets possessed by them, and do not take into account the risk preventive measures and livelihood strategies adopted by them in the face of already existing climate variability and livelihood vulnerability, respectively. This calls for an approach which can incorporate the same, as discussed in Section 4.

\section{Estimation of Loss and Damage to Floods: Proposed Capital Based approach}

One of the approaches that involve disasters and vulnerability in the development goals is the Sustainable Livelihoods Approach (SLA). The central notion of this framework is the five basic livelihood or capital assets (human, social, physical, financial, and natural) possessed by the individuals, which are used as inputs to livelihood strategies to reduce vulnerability by improving the resilience of livelihoods to stressors. However, sudden onset events like floods inflict L\&D on these assets. The proposed methodology for quantification of L\&D is thus, an extension of SLA, the theoretical underpinning of which, is shown in Fig. 5. 
Due to flood, a household is exposed to first order loss and damage, depending on the effectiveness of the risk reduction preventive measures and livelihood strategies, adopted in the face of normal climatic variability and livelihood vulnerability, respectively. In order to minimize the effects of first order impacts, household further engages in coping measures, which involve monetary and non monetary costs, and are erosive in nature. This results in second order loss and damage, making the household being trapped in vicious circle of vulnerability.

\subsection{Methodology}

This section will briefly discuss the framework for estimation of loss and damage to each of the capital asset, by floods.

\subsubsection{Human Capital}

Floods have adverse effects on human capital, especially, education, health (physical and mental), nutrition, etc. To estimate the impacts of floods on human capital, we run random effects regression of individual $i$, commune $j$, and year $\mathrm{t}$, given by equation 1 :

$\ln \left(\mathrm{HC}_{\mathrm{ijt}}\right)=\beta_{0}+\beta_{1} \mathrm{X}_{\mathrm{ijt}}+\beta_{2} \mathrm{C}_{\mathrm{jt}}+\beta_{3} F_{\mathrm{jt}}+\beta_{4} \mathrm{D}_{\mathrm{jt}}+\beta_{5} F_{\mathrm{jt}} \mathrm{X}_{\mathrm{ijt}}+\beta_{6} F_{\mathrm{jt}} \mathrm{C}_{\mathrm{jt}}+\theta_{\mathrm{i}}+\delta_{\mathrm{j}}+\epsilon_{\mathrm{ijt}}$

, where $\mathrm{HC}_{\mathrm{ijt}}$ is the human capital, proxied by education and health. The indicators of education are enrolment in primary and secondary education; and that of health is expenditure on physical and mental health. $X_{\mathrm{ijt}}$ is a vector of independent variables, which include household size, gender of children, proportion of elderly aged above 60, income of parents, attachment to occupational identity, and experience with disaster for determining the impact of flood on human capital. $\mathrm{C}_{\mathrm{jt}}$ is a vector of commune characteristics, comprising of access to educational institutions, hospital and healthcare facilities, market, road network, community cohesion, etc. The interaction effect between flood dummy $F_{\mathrm{jt}}$, and the individual specific and commune characteristics are also included as explanatory variables in the model.

\subsubsection{Social Capital}

Social capital refers to social trust, networks, participation in groups, exchanges within and among groups, community cohesion that enable collective action (Pretty, 2003; Adger, 2003; World Bank, 2004; Piya et al., 2013; Freduah et al., 2018). Here, we use the following random effects ordered probit model (equation 2):

$\ln \left(\mathrm{SC}_{\mathrm{ijt}}\right)=\beta_{0}+\beta_{1} \mathrm{X}_{\mathrm{ijt}}+\beta_{2} \mathrm{C}_{\mathrm{jt}}+\beta_{3} \ln \left(\mathrm{SC}_{\mathrm{ijt}-1}\right)+\beta_{4} \mathrm{~F}_{\mathrm{jt}}+\beta_{5} \mathrm{D}_{\mathrm{jt}}+\beta_{6} \mathrm{~F}_{\mathrm{jt}} \mathrm{X}_{\mathrm{ijt}}+\beta_{7} \mathrm{~F}_{\mathrm{jt}} \mathrm{C}_{\mathrm{jt}}+\theta_{\mathrm{i}}+\delta_{\mathrm{j}}+\epsilon_{\mathrm{ijt}}$

where, the dependent variable is the social capital, proxied by social trust, taking ordinal values. $\mathrm{X}_{\mathrm{ijt}}$ is a set of individual specific explanatory variables, like age, education status of the members, gender, occupational dummy, ethnicity, dummy for geographic location (rural, urban, and semi-urban), prior experience with disaster, participation in political organizations, dummy for attachment to place and occupation, etc. The commune characteristics included in $\mathrm{C}_{\mathrm{jt}}$ are access to market, network and groups; climate risk preventive measures taken at the Government level; access to formal and informal sources of credit; financial independence of the community, etc. The lagged value of the dependent variable is also included as a covariate.

\subsubsection{Physical Capital}

Physical capital entails energy, transport and communication, agriculture, water and sanitation, industry. A random effects regression model, of individual $\mathrm{i}$, commune $\mathrm{j}$, and year $\mathrm{t}$, as given by equation 3 can estimate the impacts of floods on physical capital:

$\ln \left(\mathrm{PC}_{\mathrm{ijt}}\right)=\beta_{0}+\beta_{1} \mathrm{X}_{\mathrm{ijt}}+\beta_{2} \mathrm{C}_{\mathrm{jt}}+\beta_{3} F_{\mathrm{jt}}+\beta_{4} \mathrm{D}_{\mathrm{jt}}+\beta_{5} F_{\mathrm{jt}} \mathrm{X}_{\mathrm{ijt}}+\beta_{6} F_{\mathrm{jt}} \mathrm{C}_{\mathrm{jt}}+\theta_{\mathrm{i}}+\delta_{\mathrm{j}}+\epsilon_{\mathrm{ijt}}$

, where $\mathrm{PC}_{\mathrm{ijt}}$ is the physical capital, the indicators of which are type of houses (bungalow, one-story, detached, etc.), type of crops, number of livestock, and fishery materials (boats, fishing nets). The explanatory variables in $X_{\mathrm{ijt}}$ are income; land ownership status; size of land holding; education of the household members; location of houses; housing conditions, type of boats, effective rainfall on crops, expenditure on fertilizers, etc. $\mathrm{C}_{\mathrm{jt}}$ is a vector of 
commune characteristics, like access to irrigation facility, electricity and water supply; access to road network; access to climate information; social capital proxied by community cohesion, etc.

\subsubsection{Financial Capital}

The direct tangible impacts of floods are the loss in income and wages, whereas, the indirect impacts include the reduced consumption of goods and services. We can model the impact of floods on financial capital, using the following random effects regression equation 4 , of individual $i$, commune $j$, and year $t$ :

$\ln \left(\mathrm{FC}_{\mathrm{ijt}}\right)=\beta_{0}+\beta_{1} \mathrm{X}_{\mathrm{ijt}}+\beta_{2} \mathrm{C}_{\mathrm{jt}}+\beta_{3} \ln \left(\mathrm{FC}_{\mathrm{ijt}-1}\right)+\beta_{4} \mathrm{~F}_{\mathrm{jt}}+\beta_{5} \mathrm{D}_{\mathrm{jt}}+\beta_{6} \mathrm{~F}_{\mathrm{jt}} \mathrm{X}_{\mathrm{ijt}}+\beta_{7} \mathrm{~F}_{\mathrm{jt}} \mathrm{C}_{\mathrm{jt}}+\theta_{\mathrm{i}}+\delta_{\mathrm{j}}+\epsilon_{\mathrm{ijt}}$

Here, the dependent variable is the financial capital, proxied by per capita income, per capita expenditure, per capita savings rate, and private credit per capita. $\mathrm{X}_{\mathrm{ijt}}$ is a set of individual specific explanatory variables, like age of household head, household size, education status of the members, per capita living area, occupational dummy, share of income sources to the total income, ethnicity, and gender of household head. Other explanatory variables determining impact of disasters on per capita expenditure are marital status of the household members, cash remittances, and receipt of government programme benefits. Another additional set of covariates for determining impact on per capita savings include income, expenditure, proportion of aged 65 and above, savings rate of various financial institutions, and labour force participation rate of household members, with an additional variable of the cost of credit to assess the impact on per capita private credit. $C_{j t}$ is a set of variables of characteristics of community $\mathrm{j}$ at year $\mathrm{t}$, which include community physical infrastructure, like access to road network, market, farms, and other infrastructure which aid in income generation; presence and access to formal (banks in rural and urban areas, micro-finance institutions, Non-Governmental Organizations offering loans) and informal sources of credit.

\subsubsection{Natural Capital}

A host of assets in a natural environment, (e.g. land resources, water resources, etc.) (Mayunga, 2007; Dhakal, 2011) and in a geographical setting (Freduah et al., 2018), which generate valuable flow of goods and services into the future, is referred to as the natural capital. The impact of floods on natural capital is modeled by using a random effects panel regression model, given by equation 5:

$\ln \left(\mathrm{NC}_{\mathrm{ijt}}\right)=\beta_{0}+\beta_{1} \mathrm{X}_{\mathrm{ijt}}+\beta_{2} \mathrm{C}_{\mathrm{jt}}+\beta_{3} \ln \left(\mathrm{NC}_{\mathrm{ijt}-1}\right)+\beta_{4} \mathrm{~F}_{\mathrm{jt}}+\beta_{5} \mathrm{D}_{\mathrm{jt}}+\beta_{6} \mathrm{~F}_{\mathrm{jt}} \mathrm{X}_{\mathrm{ijt}}+\beta_{7} \mathrm{~F}_{\mathrm{jt}} \mathrm{C}_{\mathrm{jt}}+\theta_{\mathrm{i}}+\delta_{\mathrm{j}}+\epsilon_{\mathrm{ijt}}$

, where $\mathrm{NC}_{\mathrm{ijt}}$ is the natural capital, proxied by availability of agricultural land, water resources, trees and forest products. $\mathrm{X}_{\mathrm{ijt}}$ is a vector of explanatory variables, including share of cropland area, ownership of land and boat, income, etc. The commune characteristics, given by $\mathrm{C}_{\mathrm{jt}}$ entail access to irrigation or water facility, access to road network, soil conditions, number of woodland areas or rainforests, social capital, etc.

In all the equations, from (1) to (5), $F_{\mathrm{jt}}$ is a flood dummy, i.e. whether affected households or not; and $\mathrm{D}_{\mathrm{jt}}$ is a vector of disaster damages (deaths, injuries; missing, affected, and evacuated population; houses destroyed, damaged, and submerged; damage to education centres, hospitals, and religious centres; damage to agriculture, fisheries; damage to roads and bridges; and damage to office buildings, manufacturing facilities). $\theta_{\mathrm{i}}$ and $\delta_{\mathrm{j}}$ are the individual and commune fixed effects; $\epsilon_{\mathrm{ijt}}$ is the error term. To account for the unobserved heterogeneity, a household random effect is incorporated by substituting $\epsilon_{\mathrm{ijt}}=\mu_{\mathrm{i}}+\mu_{\mathrm{ijt}}$. It is assumed that the unobserved household characteristics are uncorrelated with the covariates.

Each capital asset is a weighted average of its various indicators. Based on (Arouri et al., 2015), loss of an area $K$, due to floods, can be thus measured by the average partial effect (APE) of $F_{j t}$ and $D_{j t}$ on the log value dependent variable $\left(\mathrm{Y}_{\mathrm{ijt}}\right)$ of area $K$, with $n_{K}$ population, which measure the percentage change in indicators of human and physical capital; and social and economic capital, for area $K$, given by equations 6 and 7, respectively:

$\widehat{A P E}{ }_{\ln \left(\mathrm{Y}_{\mathrm{ijt}}\right)}$ Human (or Physical) $=\frac{1}{n_{K}}\left[\sum_{\mathrm{i} \in K}\left(\widehat{\beta_{3}}+\widehat{\beta_{5}} \mathrm{X}_{\mathrm{ij}}+\widehat{\beta_{6}} \mathrm{C}_{\mathrm{j}}\right)+\sum_{\mathrm{i} \in K} \widehat{\beta_{4}}\right]$

$\widehat{A P E} \ln \left(Y_{i j t}\right)$ Social (or Financial, Natural) $=\frac{1}{n_{K}}\left[\sum_{\mathrm{i} \in K}\left(\widehat{\beta_{4}}+\widehat{\beta_{6}} X_{i j}+\widehat{\beta_{7}} C_{j}\right)+\sum_{i \in K} \widehat{\beta_{5}}\right]$ 
As discussed earlier, an individual incurs loss and damage in two ways: first order loss and damage and second order loss and damage.The loss in each capital asset is multiplied by the proportion of households that experienced impacts, despite adopting adaptation and mitigation measures, plus the proportion of those affected households who did not adopt measures, in response, to obtain first order loss and damage, in area $K$, as shown in equation 8 and second order loss and damage, in equation 9. The households, who adopted or did not adopt climate risk preventive measures, depend on the individual's climate risk perception.

First order Loss and damage to each capital asset by floods in area $K$

$=\widehat{\mathrm{APE}}_{\ln \left(\mathrm{Y}_{\mathrm{ijt}}\right)}$ Capital Asset $*\left[\left\{\lambda_{0} * \lambda_{1} * \lambda_{2}\right\}+\left\{\left(1-\lambda_{0}\right) * \lambda_{1} * \lambda_{3}\right\}\right]$

Second order Loss and damage to each capital asset by floods in area $K$

$=\widehat{A P E}{\widehat{\ln }\left(\mathrm{Y}_{\mathrm{ijt}}\right)}^{\text {Capital Asset }} *\left[\left\{\lambda_{0} * \lambda_{1} * \lambda_{2} * \lambda_{\mathrm{c}}\right\}+\left\{\left(1-\lambda_{0}\right) * \lambda_{1} * \lambda_{3} * \lambda_{\mathrm{c}}\right\}\right]$

where, $\quad \lambda_{0}=\%$ adopted adaptation and mitigation measures to climatic stressors; $\lambda_{1}=\%$ experienced flood; $\lambda_{2}=\%$ faced flood impacts despite measures; $\lambda_{3}=\%$ experienced flood impacts without measures; and $\lambda_{c}=\%$ adopted coping measures to deal with first order loss and damage.

\subsection{Discussion}

Losses to physical capital (infrastructure and social facilities) and economic capital (income generating assets) induce losses to human capital, by reducing the disposable income and, hence the consumption for goods and services and investment in "human capital". Floods can affect the human capital by (a) reduction in disposable household income, leading to decrease in demand for education; (b) damage to the education infrastructure can increase the marginal cost of production of human capital, and lead to a decline in demand for education (Mottale et al., 2013); (c) the health problems due to disaster can reduce stock of heath, and increase in expenditure on health reduces the demand for education. Attachment to occupational identity acts as a deterrent to the household members to enrol their children in primary and secondary education. Higher the household size, more is its exposure to the floods, resulting in reduced enrolment in education. On the other hand, higher percentage of people being affected by floods can increase the opportunity cost of enrolment in education, thereby increasing human capital (Rush, 2018). Damage to road, education centres, hospitals, etc. can negatively influence human capital.

Higher education and lower age are associated with higher social capital (Kang \& Skidmore, 2018). Social capital also varies across gender and occupation, which is contextual in nature. Unlike the vertical social capital, horizontal social capital may be higher among ethnic minorities. Studies often find higher social capital in rural and semi-urban areas (Malakar et al., 2018). Similarly, a positive relationship can be found between social capital, and prior experience with disaster, participation in political organizations, and attachment to place and occupation. Fiscal independence of a community can imply that the local government has adequate fiscal capacity to meet flood recovery needs, which can enhance social trust (Kang \& Skidmore, 2018). Floods can positively influence access to credit from formal sources (banks, micro-banks, NGOs, and other institutions offering loans); and informal sources (friends, relatives, self help groups and networks). Another parameter of social capital is community/group cohesion, which may be also affected due to disasters, as studied by (Chang, 2010) through a field survey of 2005 flood in Carlisle, UK. There are two competing theories of group cohesion: (i) social identity theory which suggests that disaster strengthens community cooperation and cohesion, as the individuals understand the relevance of cooperation in protection of community and private assets from disaster; (ii) social dilemma theory which suggests that disaster can also weaken community cohesion due to the lack of cooperation from individuals, who aim to maximize their self-interests out of concerns of free-riding.

Higher income and education can positively influence physical capital. If size of land holding increases, more is the damage of floods. Floods will increase losses to physical capital, depending on the type of houses (kutcha, pucca, and semi-pucca), and the type of boats (motorized, mechanized). Floods can also impact the road network, negatively. Better access to climate information and community cohesion can negate the loss of floods to physical capital. 
A smaller household size can imply lesser influence of flood on economic capital, like, income, and savings. The various income sources can be crop income, livestock income, wage income, farm and non-farm income. Floods can result in switch from farm to non-farm activities, but a lack of skills can ultimately, result in decline in non-farm income. Floods can relatively affect households with less education. Higher the expenditure of households, lower is their savings, and more is the effect of floods. Floods cause damage to roads, which negatively influence the financial capital. Often, floods increase the probability of receiving credit from formal and non-formal sources, which can improve their financial capital in the short run, but eventually, increase their debt burden. The role of social trust plays an important role in influencing the impact of floods on financial capital.

Higher is the individual's share of cropland area, more is the effect of flood on his natural capital endowment. The number and the type of boats, used during fishing are some of the other individual specific explanatory variables. Similarly, soil conditions, access to road network and social capital also determine the impact of floods an individual's natural capital. On the other hand, the number of reforested areas, and the number of woodland areas are other relevant covariates.

The lagged values of the dependent variable are also included as covariates in the model. The model may give us differential impact of floods on each indicator for each capital asset, across different regions, depending on their exposure and vulnerability.

\section{Conclusion}

With an increasing frequency and the intensity of the floods, due to climate change, the increasing flood risks have become an increasing concern, as it has profound adverse effects on the economy. Although, mitigation and adaptation are the major two climate actions taken to tackle the problem, there is always a residual impact, which is known as the loss and damage. Section 2 introduces us to the concept of loss and damage, and discusses that L\&D occurs mainly due to four major reasons- insufficient adaptation or coping measures, irrecoverable costs, erosive coping measures, and measures not being adopted. This section also takes us along the journey of how this concept of L\&D has evolved, through various COPs, followed by an understanding of its relevance in context of floods. Section 3 discusses the different methodologies for estimation of L\&D - Damage and Loss Assessment, Post Disaster and Needs Assessment, Catastrophic Simulation, Hazus-MH, and other macro-economic models like I-O model, CGE, SAM, and econometric modelling. Although these frameworks have several advantages, and are all-inone approaches to assess the full range of disaster impacts, they can not address the livelihood context of the individuals.They have estimated "loss" and "damage", separately. However, given that the entire concept of L\&D revolves around the individuals and its starting point being the vulnerability context of the individuals, a need was felt to understand the quantification of residual"loss and damage", through the Capital based approach.

The approaches to sustainable development can help in addressing the L\&D. The mitigation and adaptation measures to climate change can be insufficient to maintain sustainable development, which results in L\&D. (Boda et al., 2021) have identified two major theories of sustainable development linked to L\&D: (i) Capital theory- maintain productive capital stock to strengthen the economic capacity for production of goods and services by recovering the capital stock and maintaining the critical level of natural capital at levels before the extreme events, and understand the values placed by individuals to place and culture, affected due to extreme events; (ii) Amartya Sen's Capabilities Approach- improve full capabilities set and thus achieve desired level of well being, in contrary to standard of living, from the extreme events scenario to achieve valued states of functioning. This calls for estimation of loss and damage to five capital assets (human, physical, financial, social, and natural), as mentioned in the Sustainable Livelihood approach, the methodology of which is discussed in Section 4. It provides us a comprehensive framework on the estimation of "loss and damage" through the lens of the vulnerability context, livelihood assets, the inter-linkages between the different capital assets, and most importantly the impacts after insufficient mitigation and inadequate adaptation measures. In the face of sudden onset events, like floods, this framework can give us estimates of first order and second order loss and damage to each capital asset.

\subsection{Limitations and future scope of the study}

This framework can be used to conduct L\&D assessment to various sudden onset meteorological, hydrological, and climatological disasters; and slow onset events, in the changing climate. However, this methodology has limitations. Firstly, such a framework, with the interaction between the disaster and the explanatory variables in determining the losses to the capital assets are contextual in nature, i.e. differential impact of different types of disaster in different 
regions may be observed. Hence, the policies must be tailored according to the type of disaster and the region or community contexts. Secondly, this framework could not incorporate the role of climate-risk perception of individuals, which plays a pivotal role. Thirdly, the depth of flooding is not taken into account as a proxy for flood, in the framework. Finally, it could not distinguish whether the adaptation measures were based on top-down or bottom-up planning, in view of reducing disparity between adaptation policy needs at national and local level.

\section{Conflict of Interest/Competing interests}

The authors declare that they have no known competing financial interests or personal relationships that could have appeared to impact the work reported in this paper.

\section{References}

Action Aid (2010) Loss and damage from climate change: the cost for poor people in developing countries. https://actionaid.org/sites/default/files/loss_and_damage_-_discussion_paper_by_actionaid-_nov_2010.pdf. Accessed 02 Feb 2021

ADB (2009) Damage Loss and Needs Assessment: An introduction for staff of the Asian Development Bank. https://www.adb.org/sites/default/files/institutional-document/31316/assessment.pdf. Accessed 10 March 2021

ADB, World Bank, United Nations India (2019) Cyclone Fani: Damage, Loss and Needs Assessmen available at https://www.recoveryplatform.org/assets/publication/PDNA2019/Webversion\%20Cyclone\%20Fani\%202019\%20Odisha\%20DLNA\%202019.07.16\%20(Re-revised\%20-\%20Final).pdf. Accessed 10 March 2021

Adger W N (2003) Social Capital, Collective Action, and Adaptation to Climate Change. Economic Geography 79(4): 387-404. https://doi.org/10.1007/978-3-531-92258-4_19

Al H, Modi I, Mishra V (2019) Increased flood risk in Indian sub-continent under the warming climate. Weather and Climate Extremes 25(100212). https://doi.org/10.1016/j.wace.2019.100212

Andersen T K, Shepherd J M (2013) Floods in a Changing Climate. Geography Compass 7(2): 95-115. https://doi.org/10.1111/gec3.12025

Arouri M, Nguyen C, Youssef A B (2015) Natural Disasters, Household Welfare, and Resilience: Evidence from Rural Vietnam. World Development 70: 59-77. https://doi.org/10.1016/j.worlddev.2014.12.017

Balica S F, Wright N G, Meulen F v (2012) A flood vulnerability index for coastal cities and its use in assessing climate change impacts. Natural Hazards 64(1): 73-105. https://doi.org/10.1007/s11069-012-0234-1

Boda C S, Faran T, Scown M, Dorkenoo K, ..., Boyd E (2021) Loss and damage from climate change and implicit assumptions of sustainable development. Climatic Change 164(13). https://doi.org/10.1007/s10584-021-02970-z

Bouwer L M (2011) Have disaster losses increased due to anthropogenic climate change. Bulletin of the American Meteorological Society 92 (1): 39-46. https://doi.org/10.1175/2010bams3092.1

Brida A-B, Owiyo T, Sokona Y (2013) Loss and damage from the double blow of flood and drought in Mozambique. International Journal of Global Warming 5(4): 514-531. https://doi.org/10.1504/ijgw.2013.057291

Cai W, Borlace S, Lengaigne M, Rensch P v, Collins M, Vecchi G,.., Jin F-F (2014) Increasing frequency of extreme El Niño events due to greenhouse warming. Nature Climate Change 4(2):111-116. https://doi.org/10.1038/nclimate2100

Cardenas V, Hochrainer S, Mechler R, Pflug G, Linnerooth-Bayer J (2007) Sovereign financial disaster risk management: The case of Mexico. Environmental Hazards 7(1):40-53. https://doi.org/10.1016/j.envhaz.2007.04.005 
Carrera L, Standardi G, Bosello F, Mysiak J (2015) Assessing direct and indirect economic impacts of a flood event through the integration of spatial and computable general equilibrium modelling. Environmental Modelling \& Software 63:109-122. https://doi.org/10.1016/j.envsoft.2014.09.016

CDCC (2008) Disaster assessment: - damage and loss assessment methodology (DALA) No.4 FOCUS Newsletter of the Caribbean Development and Cooperation Committee (CDCC) December. http://hdl.handle.net/11362/38455 Accessed 11 March 2021

Chang H, Franczyk J (2008) Climate Change, Land-Use Change,and Floods: Toward an Integrated Assessment. Geography Compass 2(5):1549-1579. https://doi.org/10.1111/j.1749-8198.2008.00136.x

Chang K (2010) Community cohesion after a natural disaster: insights from a Carlisle flood. Disasters 34(2): 289302. https://doi.org/10.1111/j.1467-7717.2009.01129.x

Dhakal S P (2011) The Five Capitals Framework for Exploring the State of Friends' Groups in Perth, Western Australia: Implications for Urban Environmental Stewardship. The International Journal of Environmental, Cultural, Economic \& Social Sustainability: Annual Review 7(2):135-147. https://doi.org/10.18848/18322077/CGP/v07i02/54902

Doelle M, Seck S (2020) Loss \& damage from climate change: from concept to remedy? Climate Policy 20(6):669680. https://doi.org/10.1080/14693062.2019.1630353

Doktycz C, Abkowitz M (2019) Loss and Damage Estimation for Extreme Weather Events: State of the Practice. Sustainability 11(15). https://doi.org/10.3390/su11154243

Doocy S, Daniels A, Murray S, Kirsch T D (2013) The Human Impact of Floods: a Historical Review of Events 1980-2009 and Systematic Literature Review. PLoS https://doi.org/10.1371/currents.dis.f4deb457904936b07c09daa98ee8171a

Dua S, Scussolini P, J Ward P, Zhang M, Wen J, Wang L,..., Aerts J C J H (2020) Hard or soft flood adaptation? Advantages of a hybrid strategy for Shanghai. Global Environmental Change 61. https://doi.org/10.1016/j.gloenvcha.2020.102037

Fankhauser S, Dietz S, Gradwell P (2014) Non-economic losses in the context of the UNFCCC work programme on loss and damage. Centre for Climate Change Economics and Policy Grantham Research Institute on Climate Change and the Environment February. http://eprints.lse.ac.uk/64554/1/Fankhauser-Dietz-Gradwell-Loss-Damage-final.pdf Accessed 25 February 2021

Freduah G, Fidelman P, Smith T F (2018) Adaptive capacity of small-scale coastal fishers to climate and non-climate stressors in the Western region of Ghana. The Geographical Journal. https://doi.org/10.1111/geoj.12282

Gajanayake A, Zhang G, Khan T, Mohseni H (2020) Postdisaster impact assessment of road infrastructure: state-ofthe-art review. Natural hazards review 21(1). https://doi.org/10.1061/(asce)nh.1527-6996.0000343

Galbusera L, Giannopoulos G (2018) On input-output economic models in disaster impact assessment. International Journal of Disaster Risk Reduction, 30:186-198. https://doi.org/10.1016/j.ijdrr.2018.04.030

Garrote J, Bernal N, Díez-Herrero A, Martins L, Bodoque J (2019) Civil engineering works versus self-protection measures for the mitigation of floods economic risk. A case study from a new classification criterion for cost-benefit analysis. International Journal of Disaster Risk Reduction 37. https://doi.org/10.1016/j.ijdrr.2019.101157

Geest K v, Warner K (2020) Loss and damage in the IPCC Fifth Assessment Report (Working Group II): a textmining analysis. Climate Policy 20 (6):729-742. https://doi.org/10.1080/14693062.2019.1704678.

GFDRR (2017a) https://www.gfdrr.org/sites/default/files/publication/PDNA\%20-\%20ACPEU\%20NDRR\%20Focus\%20Day\%20presentation\%20-\%209\%20June\%202017.pdf. https://www.gfdrr.org Accessed 18 April 2021 
GFDRR (2017b) Post-Disaster Needs Assessments Guidelines Volume B Washington D.C., April 21. https://www.recoveryplatform.org/pdna/ Accessed 24 March 2021

Goswami B N, Venugopal V, Sengupta D, Madhusoodanan M S, Xavier P K (2006) Increasing Trend of Extreme Rain Events Over India in a Warming Environment. Science 314(5804):1442-1445. https://doi.org/10.2307/20032936

H Dewan T (2015) Societal impacts and vulnerability to floods in Bangladesh and Nepal. Weather and Climate Extremes 7:36-42. https://doi.org/10.1016/j.wace.2014.11.001

Haile A T, Kusters K, Wagesho N (2013) Loss and damage from flooding in the Gambela region, Ethiopia. International Journal of Global Warming 5(4): 483-497. https://doi.org/10.1504/ijgw.2013.057290

Haque A N, Grafakos S, Huijsman M (2010) Assessment of adaptation measures against flooding in the city of Dhaka, Bangladesh. Institute for housing and development studies Erasmus University Rotterdam The Netherlands. IHS Working Papers, Number 25/2010.

Hochrainer-Stigler, S, Mechler R, Mochizuki J (2015) A risk management tool for tackling country-wide contingent disasters: A case study on Madagascar. Environmental Modelling \& Software 72: 44-55. https://doi.org/10.1016/j.envsoft.2015.06.004

Hu X, Pant R, Hall J W, Surminski S, Huang J (2019) Multi-Scale Assessment of the Economic Impacts of Flooding: Evidence from Firm to Macro-Level Analysis in the Chinese Manufacturing Sector. Sustainability 11(7). https://doi.org/10.3390/su11071933

Huq S, Roberts E, Fenton A (2013) Loss and damage. Nature Climate Change 3(11): 947-949. https://doi.org/10.1038/nclimate2026

IPCC (2001) Climate Change 2001: Impacts, Adaptation, and Vulnerability Contribution of Working Group II to the Third Assessment Report of the Intergovernmental Panel on Climate Change. Cambridge University Press Cambridge, United Kingdom and New York, USA

IPCC (2007) Climate Change 2007: Impacts, Adaptation and Vulnerability Contribution of Working Group II to the Fourth Assessment Report of the Intergovernmental Panel on Climate Change. Cambridge University Press Cambridge, United Kingdom and New York, USA

IPCC (2012a) Glossary of terms. In: Managing the Risks of Extreme Events and Disasters to Advance Climate Change Adaptation A Special Report of Working Groups I and II of the Intergovernmental Panel on Climate Change (IPCC). Cambridge University Press Cambridge, United Kingdom and New York, USA

IPCC (2012b) Managing the Risks of Extreme Events and Disasters to Advance Climate Change Adaptation A Special Report of Working Groups I and II of the Intergovernmental Panel on Climate Change (IPCC). Cambridge University Press Cambridge, United Kingdom and New York, USA

IPCC (2014) Climate Change 2014: Impacts, Adaptation, and Vulnerability Part A: Global and Sectoral Aspects Contribution of Working Group II to the Fifth Assessment Report of the Intergovernmental Panel on Climate Change. Cambridge University Press Cambridge, United Kingdom and New York, USA

IPCC (2021) Climate Change 2021: The Physical Science Basis Contribution of Working Group I to the Sixth Assessment Report of the Intergovernmental Panel on Climate Change. Cambridge University Press

Jeggle T, Boggero M (2018) Post-Disaster Needs Assessment: Lessons from a Decade of Experience. Report No.130985 European Commission GFDRR UNDP and the World Bank pp.1-72. http://hdl.handle.net/10986/30945 Accessed 24 March 2021

Jonkman S N, Kelman I (2005) An analysis of the causes and circumstances of flood disaster deaths. Disasters 29(1): 75-97. https://doi.org/10.1111/j.0361-3666.2005.00275.x 
Kajitani Y, Tatano H (2017) Applicability of a spatial computable general equilibrium model to assess the shortterm economic impact of natural disasters. Economic Systems Research 30(3): $289-312$. https://doi.org/10.1080/09535314.2017.1369010

Kang S H, Skidmore M (2018) The Effects of Natural Disasters on Social Trust:Evidence from South Korea. Sustainability 10(9). https://doi.org/10.3390/su10092973

Malakar K, Mishra T, Patwardhan A (2018) A framework to investigate drivers of adaptation decisions in marine fishing: Evidence from urban, semi-urban and rural communities. Science of The Total Environment , 637: 758-770. https://doi.org/10.1016/j.scitotenv.2018.04.429

Mayunga J S (2007) Understanding and Applying the Concept of Community Disaster Resilience: A capital-based approach. Summer academy for social vulnerability and resilience building Munich, Germany 1(1):1-16. https://theisrm.org/documents/Mayunga\%20\%282007\%29\%20Understanding\%20and\%20Applying\%20the\%20Con cept $\% 20$ of $\% 20$ Community\%20Disaster\%20Resilience\%20-\%20A\%20Capital-Based\%20Aproach.pdf. Accessed 05 February 2021

McNamara K E, Jackson G (2019) Loss and damage: A review of the literature and directions for future research. Wiley Interdisciplinary Reviews: Climate Change , 10(2). https://doi.org/10.1002/wcc.564

Mechler R, Calliari E, Bouwer L M, Schinko T, Surminski S, Linnerooth-Bayer J,..., Zommers Z (2019) Science for Loss and Damage. Findings and Propositions. In: Mechler R, Bouwer L M, Schinko T, Surminski S, LinneroothBayer J (eds.) Loss and Damage from Climate Change: Concepts, Methods and Policy Options, Climate Risk Management, Policy and Governance. Springer, Cham, Switzerland, pp. 3-36. https://doi.org/10.1007/978-3-31972026-5_1

Mechler R, Hochrainer S, Linnerooth-Bayer J, Pflug G (2006) Public Sector Financial Vulnerability to Disasters: The IIASA CATSIM Model. In: Birkmann J (ed.) Measuring Vulnerability to Natural Hazards: Towards Disaster Resilient Societies, United Nations University Press, Tokyo, Japan, pp.380-398. ISBN 9789280812022

Meehl, G A, Arblaster J M, Tebaldi C (2005) Understanding future patterns of increased precipitation intensity in climate model simulations. Geophysical Research Letters 32(18). https://doi.org/10.1029/2005gl023680

Mishra O, Ghatak M, Kamal A (2012) Flood Risk Management in South Asia. SAARC Workshop 9-10 October 2012 Islamabad Pakistan Delhi. http://www.saarcstat.org/sites/default/files/publications/Workshp\%20report\%20on\%20Flood.pdf. Accessed 30 May 2021

Monnereau I, Abraham S (2013) Limits to autonomous adaptation in response to coastal erosion in Kosrae, Micronesia. International Journal of Global Warming , 5(4): 416-432. https://doi.org/10.1504/ijgw.2013.057283 connected to glacier retreat in the Cordillera Blanca, Peru. Climatic Change. https://doi.org/10.1007/s10584-02002770-x

Mottale K A, Mohanty S, Hoang H T, M Rejesus R (2013) The effects of natural disasters on farm household income and expenditures: A study on rice farmers in Bangladesh. Agricultural Systems 121: 43-52. https://doi.org/10.1016/j.agsy.2013.06.003

Nakajima K, Morisugi H, Morisugi M, Sakamoto N (2015) Measurement of Long-Term Flood Damage in Japan using Spatial Computable General Equilibrium Model. Proceedings of the European Association of Environmental and Resource Economists 21st Annual Conference pp. 1-31. https://www.uhyogo.ac.jp/shse/nakajima/work/EAERE2015.pdf. Accessed 05 April 2021 
601 Okuyama Y (2008) Critical review of methodologies on disaster impact estimation. Background paper for 602 Economics of Disaster Risk Reduction report

603 Opondo D (2013) Erosive coping after the 2011 floods in Kenya. International Journal of Global Warming 5(4): 604 452-466. https://doi.org/10.1504/ijgw.2013.057285

605 Paavola J (2017) Health impacts of climate change and health and social inequalities in the UK. Environmental 606 Health 16(1): 61-68. https://doi.org/10.1186/s12940-017-0328-z

607 Piya L, Maharjan K L, Joshi N P (2013) Determinants of adaptation practices to climate change by Chepang 608 households in the rural Mid-Hills of Nepal. Regional Environmental Change 13(2): 437-447. 609 https://doi.org/10.1007/s10113-012-0359-5

610 Pretty J (2003) Social Capital and the Collective Management of Resources. Science 302(5652): 1912-1914. 611 https://doi.org/10.1126/science.1090847

612 Rabbani G, Rahman A, Mainuddin K (2013) Salinity-induced loss and damage to farming households in coastal 613 Bangladesh. International Journal of Global Warming 5(4): 400-415. https://doi.org/10.1504/ijgw.2013.057284

Rajeevan M, Bhate J, Jaswal A K (2008) Analysis of variability and trends of extreme rainfall events over India using 104 years of gridded daily rainfall data. Geophysical Research Letters 35(18). https://doi.org/10.1029/2008g1035143

Robinson J, Phillips W (2014) Assessment of strategies for linking the Damage and Loss Assessment Methodology to the Post-Disaster Needs Assessment. UN-ECLAC and CCRIF. https://repositorio.cepal.org/handle/11362/38355 Accessed 12 March 2021

Rose A, Liao S-Y (2005) Modeling regional economic resilience to disasters: A computable general equilibrium analysis of water service disruptions. Journal of Regional Science 45(1): 75-112. https://doi.org/10.1111/j.00224146.2005.00365.x

Rush J V (2018) The Impact of Natural Disasters on Education in Indonesia. Economics of disasters and climate change , 2(2): 137-158. https://doi.org/10.1007/s41885-017-0022-1

Sassi M, Sbia R (2010) Modeling the flood risk impact: a regional SAM analysis. CAE working paper No.78 AixEstimation Methodology I: Overview and Flood Hazard Characterization. Natural Hazards Review 7(2): 60-71. https://doi.org/10.1061/(asce)1527-6988(2006)7:2(60)

Scawthorn C, Flores P, Blais N, Seligson H, Tate E, Chang S,..., Lawrence M (2006b) HAZUS-MH Flood Loss Estimation Methodology II. Damage and Loss
https://doi.org/10.1061/(asce) $1527-6988(2006) 7: 2(72)$ Measures and Alternative Decision Frameworks. Water Resources Research 21(4): 411-424. https://doi.org/10.1029/wr021i004p00411 of Global Warming , 5(4): 498-513. https://doi.org/10.1504/ijgw.2013.057288

Trenberth K E (2011) Changes in precipitation with climate change. Climate Research 47(1):123-138. https://doi.org/10.3354/cr00953 
641 Tripathi P (2015) Flood Disaster in India: An Analysis of trend and Preparedness. Interdisciplinary Journal of 642 Contemporary Research , 2(4): 91-98

643 UNFCCC (2008a) Alliance of Small Island States (AOSIS), Proposal to the AWG- LCA: Multi-window Mechanism 644 to Address Loss and Damage from Climate Change Impacts. 645 https://unfccc.int/files/kyoto_protocol/application/pdf/aosisinsurance061208.pdf (accessed 18 January 2021)

646 UNFCCC (2008b) Report of the Conference of the Parties on its thirteenth session, held in Bali from 3 to 15 647 December 2007 Addendum Part Two: Action taken by the Conference of the Parties at its thirteenth session. 648 https://unfccc.int/documents/5079. Accessed 18 January 2021

649 650 651

652

653

654

655

656

657

658

659

660

661

662

663

664

665

666

667

668

669

670

671

672

673

674

675

676

677

678

679

680

681

682

683

684

UNFCCC (2010) Report of the Conference of the Parties on its sixteenth session, held in Cancun from 29 November to 10 December 2010 Addendum Part Two: Action taken by the Conference of the Parties at its sixteenth session. https://unfccc.int/documents/6527. Accessed 18 January 2021

UNFCCC (2011) Report of the Conference of the Parties on its seventeenth session, held in Durban from 28 November to 11 December 2011 Addendum Part Two: Action taken by the Conference of the Parties at its seventeenth session. https://unfccc.int/resource/docs/2011/cop17/eng/09.pdf. Accessed 18 January 2021

UNFCCC (2012a) A literature review on the topics in the context of thematic area 2 of the work programme on loss and damage: a range of approaches to address loss and damage associated with the adverse effects of climate change. https://unfccc.int/resource/docs/2012/sbi/eng/inf14.pdf . Accessed 18 January 2021

UNFCCC (2012b) Report of the Conference of the Parties on its eighteenth session, held in Doha from 26 November to 8 December 2012 Addendum Part Two: Action taken by the Conference of the Parties at its eighteenth session. https://unfccc.int/documents/7644. Accessed 18 January 2021

UNFCCC (2014) Report of the Conference of the Parties on its nineteenth session, held in Warsaw from 11 to 23 November 2013 Addendum Part Two: Action taken by the Conference of the Parties at its nineteenth session. https://unfecc.int/documents/8105. Accessed 18 January 2021

UNFCCC (2016) Report of the Conference of the Parties on its twenty-first session, held in Paris from 30 November to 13 December 2015 Addendum Part Two: Action taken by the Conference of the Parties at its twenty-first session. https://unfccc.int/resource/docs/2015/cop21/eng/10.pdf . Accessed 18 January 2021

UNFCCC (2017) Report of the Conference of the Parties on its twenty-second session, held in Marrakech from 7 to 18 November 2016 Appendum Part Two: Action taken by the Conference of the Parties at its twenty-second session. https://unfccc.int/documents/9673. Accessed 18 January 2021

UNFCCC (2018) Report of the Conference of the Parties on its twenty-third session, held in Bonn from 6 to 18 November 2017, Addendum, Part Two: Action taken by the Conference of the Parties at its twentythird session. https://unfccc.int/documents/65126. Accessed 18 January 2021

UNFCCC (2019) Report of the Green Climate Fund to the Conference of the Parties and guidance to the Green Climate Fund. https://unfccc.int/documents/202123. Accessed 19 January 2021

Van der Geest K, Schindler M (2017) Handbook for assessing loss and damage in vulnerable communities. United Nations University Institute for Environment and Human Security (UNU-EHS), Bonn. http://collections.unu.edu/eserv/UNU:6032/Online_No_21_Handbook_180430.pdf. Accessed 23 January 2021

Wallemacq P (2018) Economic Losses, Poverty \& Disasters 1998-2017 Centre for Research on the Epidemiology of Disasters (CRED) and the United Nations Office for Disaster Risk Reduction (UNISDR). https://www.undrr.org/publication/economic-losses-poverty-disasters-1998-2017. Accessed 30 May, 2021

Wallimann-Helmer I, Meyer L, Mintz-Woo K, Schinko T, Serdeczny O (2019) The Ethical Challenges in the Context of Climate Loss and Damage. In: Mechler R, Bouwer L M, Schinko T, Surminski S, Linnerooth-Bayer J (eds.) Loss and Damage from Climate Change: Concepts, Methods and Policy Options, Climate Risk Management, Policy and Governance. Springer, Cham, Switzerland, pp. 39-61. https://doi.org/10.1007/978-3-319-72026-5_2 
Warner K, Van der Geest K (2013) Loss and damage from climate change: local-level evidence from nine vulnerable countries. International Journal of Global Warming 5(4): 367-386. https://doi.org/10.1504/ijgw.2013.057289

World Bank (2004) Social $\quad$ Capital. www.worldbank.org/en/webarchives/archive?url=http\%3A\%2F\%2Fweb.worldbank.org\%2Farchive\%2Fwebsite013 60\%2FWEB\%2F0_MEN-2.HTM\&mdk=23354653. Accessed 23 April 2021

World Bank Group (2005) Indonesia: Preliminary Damage and Loss Assessment: the December 26, 2004 Natural Disaster. BAPPENAS and The International Donor Community World Bank Washington D C. http://documents.worldbank.org/curated/en/732201468773057989/Indonesia-preliminary-damage-and-lossassessment-The-December-26-2004-natural-disaster. Accessed 12 March 2021

World Bank Group (2010) Haiti Earthquake PDNA:Assessment of damage, losses, general and sectoral needs. World Bank Washington D C. http://documents.worldbank.org/curated/en/355571468251125062/Haiti-earthquakePDNA-Post-Disaster-Needs-Assessment-assessment-of-damage-losses-general-and-sectoral-needs. Accessed 26 March 2021

World Bank Group (2015) Nepal Earthquake Post Disaster Needs Assessment: Sector Reports. World Bank Washington D C. http://hdl.handle.net/10986/22096. Accessed 25 March 2021

World Bank Group (2017) Sierra Leone: Rapid Damage and Loss Assessment of August 14, 2017 landslides and floods in the Western Area. World Bank Washington D C. http://hdl.handle.net/10986/28836. Accessed 11 March 2021

World Health Organization (NA) https://www.who.int/health-topics/floods\#tab=tab_2. https://www.who.int. Accessed 31May 2021

Yaffa S (2013) Coping measures not enough to avoid loss and damage from drought in the North Bank Region of The Gambia. International Journal of Global Warming 5(4):467-482. https://doi.org/10.1504/ijgw.2013.057286

Yildirim E, Demir I (2019) An integrated web framework for HAZUS-MH flood loss estimation analysis. Natural Hazards 99(1): 275-286. https://doi.org/10.1007/s11069-019-03738-6

Zhang L (2016) Flood hazards impact on neighborhood house prices: A spatial quantile regression analysis. Regional Science and Urban Economics 60:12-19. https://doi.org/10.1016/j.regsciurbeco.2016.06.005 


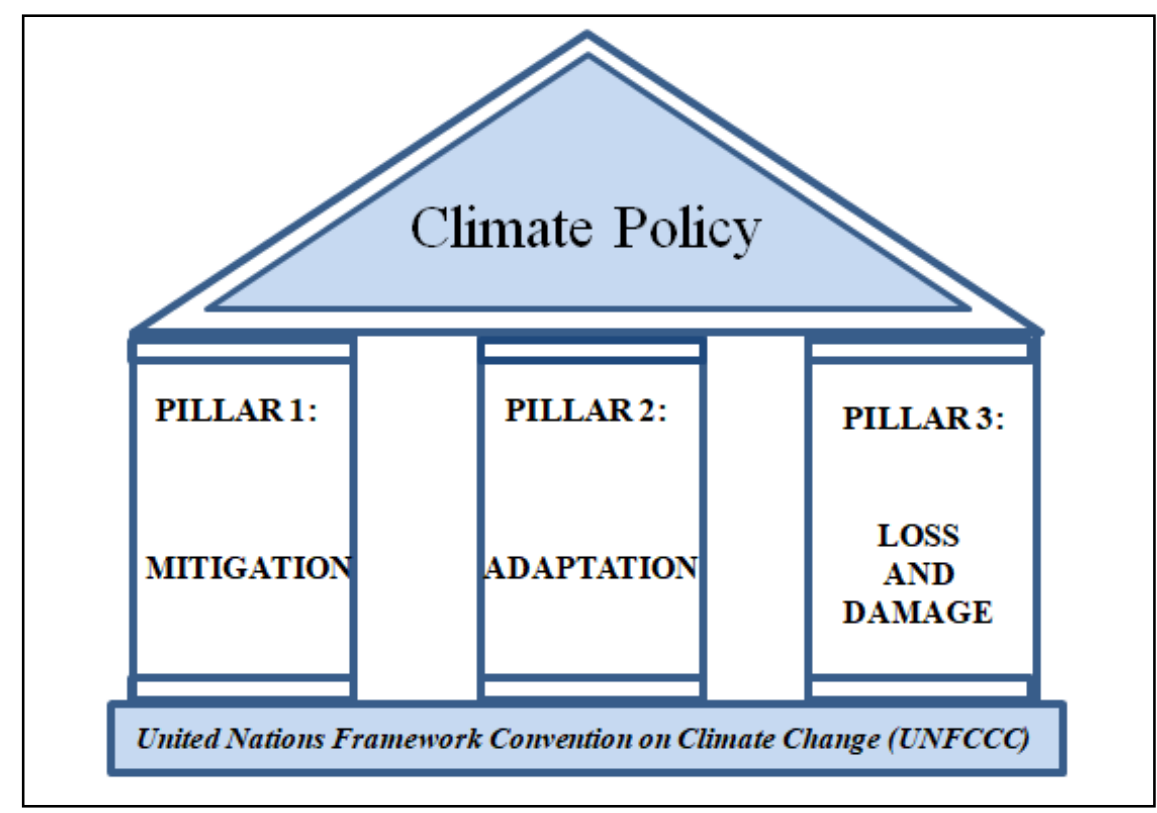

Fig. 1 Three Pillars of Climate Policy, conceptualized from (Wallimann-Helmer et al., 2019)

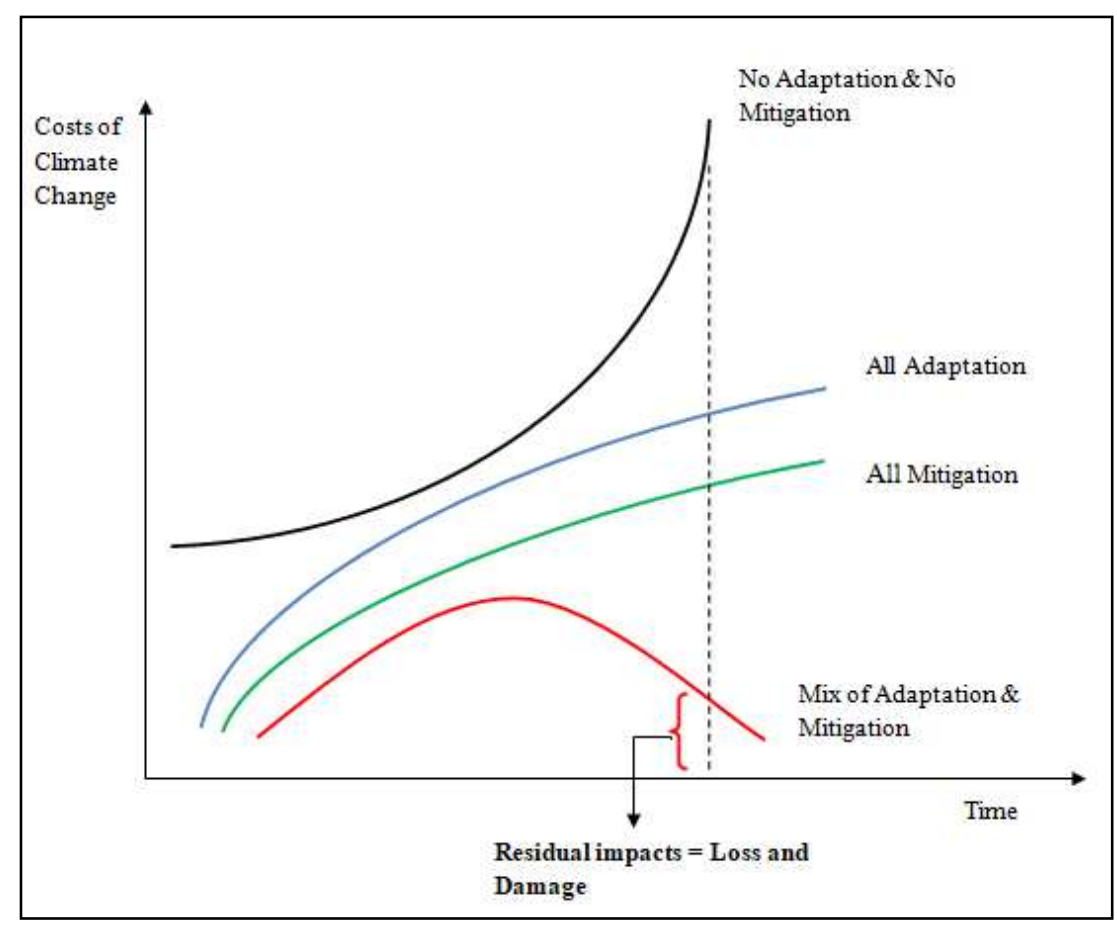

Fig. 2 Graphical Representation of Loss and Damage 


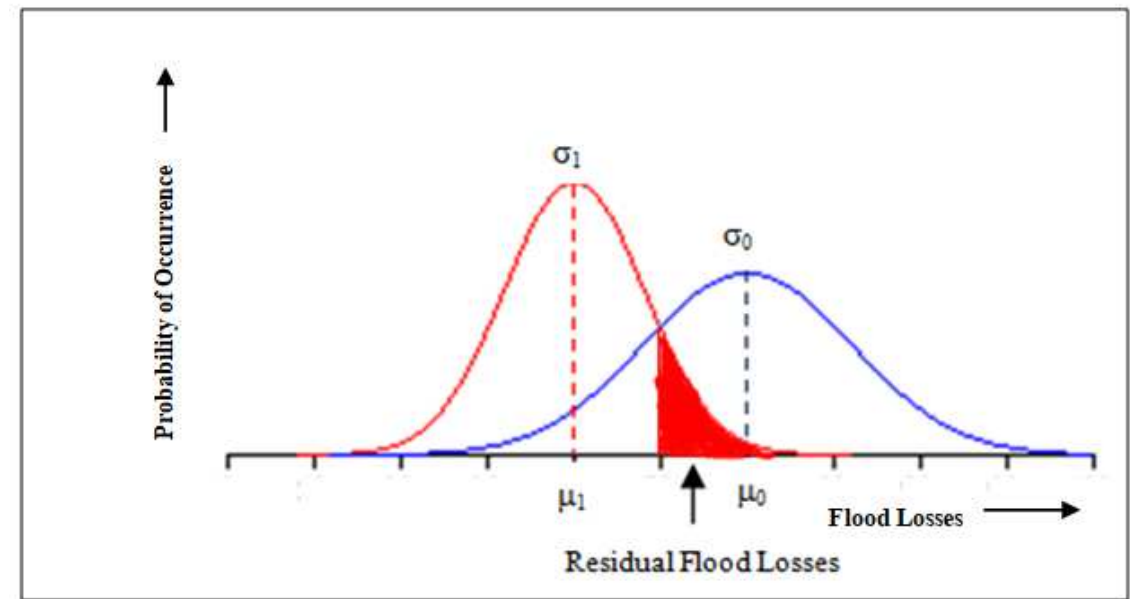

Fig. 3 Concept of Loss and damage, in floods

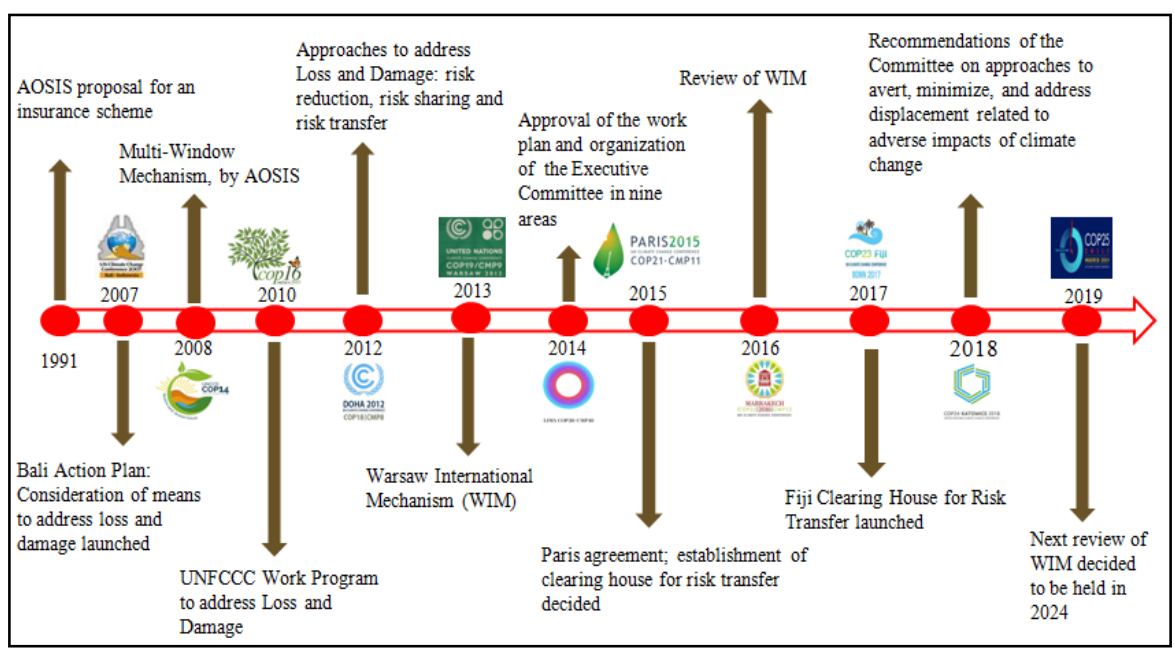

Fig. 4 History of Loss and Damage 


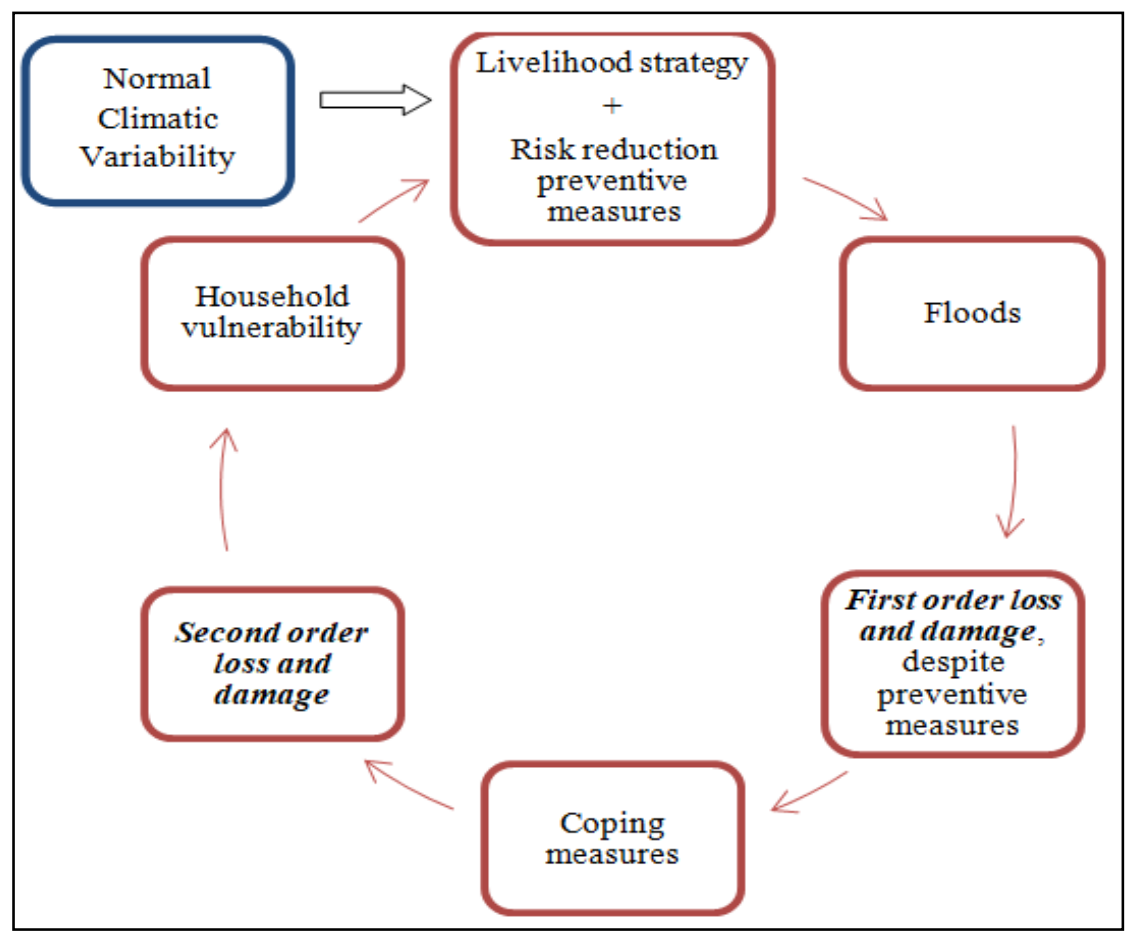

Fig. 5 Vicious Circle of Vulnerability, in face of floods (Van der Geest \& Schindler, 2017) 